\title{
Analysis of Factors Influencing Adoption of Human Resource Practices by Small and Medium Scale Enterprises in Nigeria
}

http://doi.org/10.21272/bel.4(2).16-25.2020

Rukayat Oloruntoyin Rabiu, ORCID: https://orcid.org/0000-0001-9781-039X

M.Sc., Part-Time Lecturer, Department of Business Administration, Faculty of Management Sciences, Al-Hikmah University, Ilorin, Nigeria

Wahid Damilola Olanipekun, ORCID: https://orcid.org/0000-0002-9651-6655

$\mathrm{PhD}$, Lecturer, Department of Management and Accounting, College of Management and Social Sciences, Summit University, Offa, Nigeria

Ayodeji Gbenga Bamidele, ORCID: https://orcid.org/0000-0003-1114-0714

$\mathrm{PhD}$, Course Facilitator, Department of Business \& Entrepreneurship, School of Business and Governance, Kwara State University, Malete, Nigeria

Olasehinde Israel Awe, ORCID: https://orcid.org/0000-0002-8721-0318

M.Sc., Lecturer, Department of Business Administration \& Management, Kwara State Polytechnic, Ilorin, Nigeria

\begin{abstract}
In the XXI century, one of the most valuable resources of any organization is human capital. The effectiveness of the organization and the use of other resources depend on the formation quality and the use of the human capital. Today, many factors affect small and medium scale enterprises that lead to their rapid bankruptcy and liquidation, significant staff turnover and reduced productivity. Under these conditions, attracting and retaining highly qualified personnel as the primary determinant of economic development and growth of small and medium scale enterprises is significantly relevant. Minimizing the negative impact of external and internal factors made by small and medium scale businesses requires recognition of the value of the human resources in improving the enterprise's competitiveness and the effective management tools implementation. The study identifies the main factors influencing the implementation of human resource management practices in small and medium scale enterprises in Kwara, Nigeria. Methodological tools of this study are methods of analysis and synthesis, comparative and regression analysis. The study covers 200 small and medium scale enterprises in the Kwara Central Senatorial District and registered in the National Association of Small and Medium Enterprises (NASME). The factors influencing the use of human resources by small and medium scale enterprises in the article are studied in the following logical sequence: using a structured questionnaire developed in the form of the Rensis Likert scale, an array of primary data is forme. The hypothesis (at the level of 5\% of weight) regarding the relationship between the efficiency indicators and human resources management policy is tested using multiple regression analysis with statistical software STATA 11.0. The results of the survey are analyzed, summarized and interpreted using descriptive statistical methods. The results of multiple regression analysis confirm a statistically significant relationship between the analyzed indicators $\left(p=0.000\right.$ and $\left.R^{2}=0.8128\right)$. The study shows a significant impact of financial security of the organization $(\beta=0.76 ; t=8.63 ; p)$ and its size $(\beta=0.46 ; t=4.66 ; p)$ on the implementation of personnel management practices on the example of small and medium scale enterprises in Kwara). The study results confirm that the small and medium scale enterprises in Kwara actively use personnel management under the influence of environmental factors. The study empirically confirms and theoretically proves the feasibility to consider such variables as the funding availability, the size of the firm and the type of ownership in the business management process.
\end{abstract}

Keywords: Human Resources, Human Capital Theory, Management, Nigeria, Small and Medium Scale Enterprises. JEL Classification: O15, M10, L11.

This work is licensed under a Creative Commons Attribution 4.0 International License

Cite as: Rabiu, R. O., Olanipekun, W. D., Bamidele, A. G., Awe, O. I. (2020). Analysis of Factors Influencing Adoption of Human Resource Practices by Small and Medium Scale Enterprises in Nigeria. Business Ethics and Leadership, 4(2), 16-25. http://doi.org/10.21272/bel.4(2).16-25.2020.

(C) The Authors, 2020. This article is published with open access at Sumy State University. 
Business Ethics and Leadership, Volume 4, Issue 2, 2020

ISSN (online) - 2520-6311; ISSN (print) - 2520-6761

\section{Introduction}

Human resources are the most important resources or asset an organization can boast of in the $21^{\text {st }}$ century workplace since organization are run and steered by people. It is through people that goals are set, and objectives attained (Ibikunle, 2014). Thus, the performance of an organization is dependent on the total sum of the performance of its members. Ojokuku (2012) opine that it is indeed very difficult for any organization to succeed without managing its human resources effectively. Ojokuku (2012) opined that recent research attention had revealed the increased interest that scholars place on the pivotal role that Human Resource Management (HRM) plays in Small and Medium Scale Enterprises (SMEs). HRM is becoming increasingly important in the new "knowledge-based" economy, as companies constantly require the need for highly trained employees. It has subsequently reinforced the need for effective HRM practices in small firms (Audretsch \& Klepper, 2000). It is therefore not surprising that research on HRM practices in small and medium-sized enterprises has captured increased attention in recent years. SMEs just like any other enterprise needs employees with certain skills, training and specific experience.

The importance of HRM practices adoption cannot be overemphasized in the life of SMEs because they rely more heavily on individual employees' contributions that their larger counterparts. Business organizations, irrespective of their size or objectives, all have the philosophy of growth, survival and adaptiveness and their inability to maintain this philosophy can be regarded as a business failure (Lawal, 1998). In Nigeria, despite several efforts of the government in the development of SMEs to ensure their continuous survival, Akabueze (2002) opine that one would have thought that they would flourish and grow but the reverse is the case because of some challenges that is associated with managing businesses in Nigeria. Saka (2009) in examining the problems affecting the business classified them into two main categories internal factors and external factors.

Okwuonu (2009) opined that the root cause of business failure is inadequate management, which is borne out of the failure to adopt a sound human resource management practice. It has led to a high mortality rate of SMEs. Osalor (2010) opine that SMEs have also been affected by the lack of enabling environment. It has led to their sudden death. This implies that there are no growth-propelling resources at the disposal of SMEs in Nigeria over the years and these tend to deteriorate their growth mechanisms (Sangosanya, 2011). Oshagbemi (1983) stated that less than five out of every twenty SMEs established in Nigeria survive in their first year of operation. Onnumere (1992) in a study conducted over thirty years on SMEs stated that half of SMEs in Nigeria do not survive beyond half a century. Unfortunately, this mortality rate is not confined to new entrants; it also affects older established SMEs (Oshagbemi, 1983). Despite the increase in the rate of failure of SMEs, entrepreneurs continue to venture into it and it will be to the disadvantage of the economy considering the pivotal roles of SMEs if these bottlenecks, obstacles and challenges to the performance and sustenance of SMEs are not addressed. It is pertinent that all the factors mentioned have their solution lying on the feet on the feet of the external environment, such as the government except the factor of competent personnel, which has its solution with the entrepreneur himself (Ogunwoye, 2015).

\section{Statements of problem}

The alarming rate of SMEs failure and discontinuations give the Nigerian economy cause for concern; there is, therefore, urgent need to research on factors that influence the adoption of HRM practices which may be responsible for influencing SMEs growth and performance in the area of study to prevent their total extinction from the Nigerian industrial sector. Small and Medium Scale Enterprises (SMEs) were key players in the sustainable development of both the developed nations and the developing economies of Third World countries, owing to their contribution to all aspects of the phenomenon. In Africa, the SME sector is the largest source of employment and constitutes the backbone of almost every economy on the continent. (Ojokuku, Sajuyigbe \& Ogunwoye, 2014). Small-scale enterprises are important for the modern economy and it is widely recognized that they contribute to employment growth (Drucker, 1985). About $99 \%$ of all European companies are small and medium-sized and they provide $66 \%$ of all working places. Over the last decade, enterprises with less than ten employees provided more new jobs than bigger companies (Mulhern, 1995). Small and Medium Scale businesses constitute a driving force for economic growth, job creation, and poverty reduction in developing countries. In Nigeria, the informal economy has grown to a stage where it contributes over $65 \%$ of Gross National Product and accounts for more than $70 \%$ of all new jobs in the country (Osalor, 2010). Despite the significant position Nigeria 
enjoys as the giant of Africa, in terms of natural resources, majority of firms predominantly small and medium scale enterprise still underperform while others wind up within first five years of business, only five to ten per cent survive to achieve maturity stage, even with available financial resources (Ayanda \& Danlami, 2011; Onugu, 2005), due to lack of strategic human resource planning (Okpara, 2011). This research addressed an important dearth identified in the literature regarding factors that influences the adoption of HRM practices of SMEs in Kwara state. From the foregoing, the objective of this research is to investigate the factors that influence the adoption of HRM practices by SMEs in Kwara State.

\section{Literature review}

\subsection{Conceptual Crystallization}

Small and Medium Scale Enterprises. SMEs are one concept that has a nebulous meaning as different countries of the world consider various unique factors that are peculiar to them in their conceptualization of the idea. These varying factors include the degree of the country's industrialization viz-a-viz its extent of economic development (Otokiti, 1987). It is fundamentally the reason why the concept does not have any universally accepted definition. In Nigeria, just like other countries of the world, factors such as asset base (excluding land), the number of employees, and the annual turnover of the business amongst others are usually considered. Otokiti (1987) juxtaposed this by also emphasizing that the meaning SMEs are dynamic. Olutunla (2001) avers that in a review of different definitions of SMEs, parameters such as employee's size, asset base, turnover, financial strength, working capital and size of the business are considered. Small and Medium Enterprise Equity Investment Scheme (SMEEIS), a private initiative by the Bankers' Committee defined MSME as enterprises with an asset base not exceeding \$3.85 million (500 million) excluding land and working capital with staff strength of not less than ten and not more than 300 (Sanusi, 2003). Pacific Economic Cooperation Council (2003) also opined that the International Finance Corporation (IFC) defined SMEs as firms with less than 300 employees and total assets less than 15 million US dollars. The corporation adds that in smaller economies, SMEs are defined as firms with less than 20 employees.

Oyeyinka (2011) opined that SMEs are broadly defined as businesses with a turnover of less than 100 million per annum and/or less than 300 employees. For Small and Medium Equity Investment (SMESEI) scheme, SMEs are defined as the enterprise with a maximum asset base of 500 million (excluding land and working capital) and with no lower or upper limit of staff. The CBN in its monetary policy circular no 22 of 1988 defined small scale enterprise as having an annual turnover not exceeding 500,000. Oyeyinka also stated that the National Council of Industries refers to business enterprises whose total cost excluding land is not more than two million.

The Third National Development Plan (1975-1980) defined SMES as a manufacturing establishment employing less than 200 people or whose investment in equipment and machinery exceeds five million. Abdul Majeed (2002) opined that the Federal Ministry of Industries defined SMEs as any manufacturing, processing or services with capital investment not more than 150 million in machinery and equipment alone. Section 37b (2) of the Companies and Allied Matters Decrees of 1990 defines a small company as one with an annual turnover of not more than two million and net asset value of not more than one million. The European Commission (2007) also defined SMEs as an enterprise, which employs fewer than 250 persons and which has an annual turnover not exceeding 50 million Euro, and /or annual balance sheet total not exceeding 43 million Euro.

The above shows clearly that there is no clear-cut definition of SMEs as the various definitions are centered on one or a combination of criteria such as the number of employees, sales turnover, capital outlay, asset base, etc. One would quite agree that indeed definitions of SMES vary from country to country and even in the same country, it varies from sector to sector as different institutions may adopt different definitions depending on the policy focus. It is also quick to note that these definitions change overtime. In furtherance of this, the National Council on Industry (2001) emphasized that there is a need to disaggregate what constitutes SMEs.

Micro/Cottage Industry: An enterprise that has not more than ten employees with total cost of not more than 1.50 million, including working capital but excluding the cost of land.

$>$ Small-Scale Industry: An enterprise that has employees ranging between 11-100 workers with a total cost of not more than 50 million, including working capital but excluding the cost of land. 
> Medium Scale Industry: An enterprise that has employees ranging between 101-300 workers with a total cost of over 50 million but not more than 200 million, including working capital but excluding the cost of land.

$>$ Large Scale: An enterprise having over 300 workers with a total cost of over 200 million, including working capital but excluding the cost of land.

Human Resource Management Practices. In the $21^{\text {st }}$ century, human resources are the most important resources an organization can boast of since it ensures the efficient and effective utilization of other types of resources. Therefore, organizations must continually engage in attracting and retaining human resources (Ibikunle, 2014). The term HRM is widespread, the definition of the term has remained varied and elusive. HRM is a unique approach that seeks to achieve competitive advantage through the strategic deployment of the highly committed and capable workforce, using an integrated array of cultural, structural and personnel techniques".

Human Resource Management (HRM) is a strategic, integrated and coherent approach to the employment, development and well-being of the people working in organisations. To Boxall and Purcell (2008), HRM is the management of work and people towards desired ends. Som (2008) described HRM as carefully designed combinations of such practices geared towards improving organisational effectiveness and hence better performance outcomes. Human resource management has been defined as all management decisions and actions that affect the relationship between the organisation and employees.

HRM practices are activities of the organisation that aims at efficient and effective management of human resources to facilitate and achieve the fulfilment of organisational goals (Schuler \& Jackson, 1987; Schuler \& MacMillan, 1984). In most organisations, human resource management is grouped under several functions namely Human Resource Planning, Recruitment, Selection, Placement and Induction, Training and Development, Performance Appraisal, Employee Compensation, Welfare Services and Benefits, Industrial Relations.

\subsection{Theoretical Framework - Human Capital Theory}

The human capital theory advocates education as a tool for improving human capital, stimulating labour productivity and boosting the levels of technology across the globe (Robert, 1991). This is so because Human capital is the most important resource or asset an organization or a country can boast of in the $21^{\text {st-century }}$ workplace since organizations are run and steered by people and it is through people that goals are set and objectives attained. Human capital consists of skills and knowledge that individuals acquire through investments in schooling, on-the-job training, and other types of experience. From microeconomics perspective, the human capital theory suggests that people possess skill, knowledge, and ability that has the potential to generate economic rent. Economic rent refers to profits over the formal economic returns (Coff, 2007).

Like other assets, human capital has value in the market place, but unlike other assets, the potential value of human capital can be fully realized only with the cooperation of the person, since firm investment to increase employee skills, knowledge, and abilities carry a cost to the organization, they are only justified if they produce future returns using increased productivity and overall firm performance.

Human capital is recognized as the most critical in development. It has been directly linked to the ability of nations to transform from underdeveloped to developed economies. Indeed, the quality of a country's human capital is central to promoting and sustaining innovation as well as the adoption of appropriate technology for accelerated sustainable development (Ajibade, 2013). That human capital was largely accountable for the transformation of resource-poor countries like South Korea, Taiwan and Singapore while resource-rich countries like Nigeria, Venezuela and Angola are still at the lower rung of the development ladder is a fact. This point re-iterates the case for accelerated human capital development, especially in the developing countries, if the world is to overcome the global socio-economic and ecological crisis that has the potential to endanger our individual and collective existence as well as rob future generations of their well-being.

The search for sources of sustainable competitive advantage increasingly pointed inward towards organizational capability and more specifically, to the strategic management of human resources as capital and technology become increasingly available to virtually anyone anywhere. Human capital fundamentally entails the skills, experience and knowledge that are of high economic value which employees bring to the organisation. They are what constitute the productive capabilities of employees. 


\subsection{Empirical Review}

Madurapperuma (2009) studied informal HRM practices and the level of performance in manufacturing SMEs in Sri-Lanka. He identified that achievements of SMEs are determined by various factors such as management process, marketing, strategies, networks, Human Resources Management (HRM) practices, technology (information and production technology) and so on. According to him, adoption of such practices and the extent to which those are put in place depends upon management and workforce of an organization. He concluded that, without having positive support from the workforce, it is difficult to obtain desired results even though other practices such as marketing strategies, management process and network are apparent in the firm. His study ascertains whether manufacturing SMEs adopt formal human resources management practices in the same manner as large organizations. He concluded that informal HRM practices positively correlated with higher business performances. He described that more formal HRM practices are seen in SMEs where product quality is a concern and the numbers of employees are large.

Abdulkadir (2012), in his research, investigated the extent the SHRM was effective in achieving organizational performance in the Nigerian Insurance Industry. Descriptive statistics of mean and standard deviation as well as inferential statistics of correlation analysis were used to test the hypothesis. Findings from the results revealed that organizational climate significantly moderates the relationship between SHRM practices and organizational performance in the Nigerian insurance industry. Furthermore, the findings from the results revealed that strategic alignment, training, selection system, career planning, and job definition were significant to the performance level of the organization. Muogbo (2013) researched the effect of SHRM on manufacturing SMEs in Anambra State Nigeria using 17 paint manufacturing firms. The authors used correlation analysis to test the hypothesis and a 5\% level of significance. Findings from the results revealed that there was a strong positive correlation between SHRM and performance level of competition in SMEs.

Subramanian, Ibrahim and Shamsudin (2011) studied, linking human resource and organizational performance: evidence from small and medium organizations in Malaysia. In their study, HR practices, namely compensation, information sharing, job security and training and development are considered. According to them, compensation influences the employee and organizational performance and Information sharing improve organizational performance. They explained that in small and medium enterprises trust is essential among the small workforce, which enables the organization to gather relevant input for critical decision making for the success of the organization. According to them for the smaller workforce, it is easy for the organization to share information about the day to day running of the organization and this makes the employee feel a sense of belongingness and improves organizational performance. They concluded that Training and development improve organizational necessary skill and knowledge enhances work performance of employees and organizational performance.

\section{Methodology}

This study adopted the survey strategy in which it is descriptive and was inductive in approach. Additionally, this study has a population of 200 SMEs whose businesses are situated in Kwara Central Senatorial District and who are registered with the National Association of Small and Medium Enterprises (NASMEs). Primary data with the aid of a structured questionnaire was employed. The close-ended questionnaire was designed using Rensis Likert scale format and administered to owners of selected SMEs. Data collected from the questionnaire were analyzed, summarized, and interpreted accordingly with the aid of descriptive statistical techniques such as total score and simple percentage. Multiple regression analysis was adopted to show the degree of impact of HRM practices on SMEs performance. The hypotheses were tested at a 5\% level of significance with the aid of STATA 11.0 Computer statistical software.

\section{Result and Discussion}

Table 1. Summary of Demographic Characteristics of Respondents

\begin{tabular}{|l|l|c|c|}
\hline S/N & \multicolumn{1}{|c|}{ Items } & Frequency & Percentage (\%) \\
\hline \multirow{3}{*}{1.} & Gender & & 69.23 \\
\cline { 2 - 5 } & Male & 135 & 30.77 \\
\cline { 2 - 5 } & Female & 60 & $\mathbf{1 0 0 . 0 0}$ \\
\hline & Total & $\mathbf{1 9 5}$ & \\
\hline
\end{tabular}


Table 1 (cont.). Summary of Demographic Characteristics of Respondents

\begin{tabular}{|c|c|c|c|}
\hline \multirow[t]{6}{*}{2.} & Age & & \\
\hline & $20-29$ & 42 & 21.54 \\
\hline & $30-39$ & 67 & 34.36 \\
\hline & $40-49$ & 52 & 26.67 \\
\hline & 50 and above & 34 & 17.44 \\
\hline & Total & 195 & 100.00 \\
\hline \multirow[t]{5}{*}{3.} & Marital status & & \\
\hline & Single & 129 & 66.15 \\
\hline & Married & 44 & 22.56 \\
\hline & Others & 22 & 11.28 \\
\hline & Total & 195 & 100.00 \\
\hline \multirow[t]{6}{*}{4.} & Academic Qualification & & \\
\hline & NCE/ ND & 66 & 33.85 \\
\hline & HND/BSc. & 87 & 44.62 \\
\hline & Masters & 28 & 14.36 \\
\hline & Others & 14 & 7.18 \\
\hline & Total & 195 & 100.00 \\
\hline \multirow[t]{4}{*}{5.} & Business Type & & \\
\hline & Manufacturing & 105 & 53.85 \\
\hline & Service & 90 & 46.15 \\
\hline & Total & 195 & 100.00 \\
\hline
\end{tabular}

Source: Researchers' Field Survey, 2019

Table 1 is a bird eye's view of the demographic information of respondents. Hence, the first column discusses the gender analysis where the male has 135 respondents amounting to $69.23 \%$ and the female has 60 respondents with $30.77 \%$. It means that there are more male respondents in this study than the female counterpart. Also, the age column showed that $21.54 \%$ of the respondents fell within the age of $20-29$ years, while $34.36 \%$ fell between $30-39$ years, $26.67 \%$ of ages of $40-49$ years while $17.74 \%$ for the ages of 50 years and above. The highest percentage of $34.36 \%$ was in the active years of age. It also shows that majority of the respondents are within the working age. Additionally, the third column presented the marital status of the respondents which revealed that married people have $66.15 \%$ of the respondents; single has $22.56 \%$ while others have $11.28 \%$. It implies that more than half of the respondents are married. The fourth column consisted of the academic qualification revealed a pool of literate and educated SMEs owners. 33.85\% of the respondents have ND/NCE, $44.62 \%$ of the respondents also have B.SC /HND, 14.36\% with MBA /M.SC while 7.18\% of the total respondents have other certificates. Lastly, the fifth column described the two different sectors under study, where the service sector has the total respondents of 90 with $46.15 \%$ and manufacturing sector has 105 respondents with $53.85 \%$ sampled in the study. It means that more than half of the sampled respondents which has $53.854 \%$ are from the manufacturing sector.

Table 2. Respondents Perception on Factors influencing adoption of HRM practices by SMEs

\begin{tabular}{|l|l|c|c|c|c|c|}
\hline S/N & \multicolumn{1}{|c|}{ Items } & $\begin{array}{c}\text { Strongly } \\
\text { agree }\end{array}$ & Agree & Undecided & Disagree & $\begin{array}{c}\text { Strongly } \\
\text { Disagree }\end{array}$ \\
\hline 1 & $\begin{array}{l}\text { The size of our organisation is a major factor that } \\
\text { influence the adoption of HRM practices }\end{array}$ & $116(59.49)$ & $35(17.95)$ & $39(20)$ & $5(2.56)$ & $0(0)$ \\
\hline 2 & $\begin{array}{l}\text { The policies of government on HRM matters } \\
\text { influence adoption of HRM practices }\end{array}$ & $91(46.67)$ & $68(34.87)$ & $36(18.46)$ & $0(0)$ & $0(0)$ \\
\hline 3 & $\begin{array}{l}\text { The type of ownership of our organisation influence } \\
\text { ion of HRM practices }\end{array}$ & $78(40)$ & $27(13.85)$ & $58(29.75)$ & $30(15.38)$ & $0(0)$ \\
\hline 4 & $\begin{array}{l}\text { Availability of financial resources to execute HRM } \\
\text { practices influence the adoption of HRM practices }\end{array}$ & $96(49.23)$ & $66(33.85)$ & $20(10.26)$ & $12(6.15)$ & $1(0.51)$ \\
\hline
\end{tabular}

Source: Researchers' Field Survey, 2019

Table 2 revealed that most of the respondents with $77.44 \%$ agreed that the size of the firm is a significant factor that influences the adoption of HRM practices. $20.00 \%$ were undecided, while 2.56 disagreed. The open-ended questions that sought to confirm the extent to which it influences also revealed that due to the nature of SMEs, they could not implement some HRM practices like big organizations. Also, the table revealed that most of the respondents with $81.54 \%$ agreed that the policies of government on HRM matters influence the adoption of HRM 
practices, $18.46 \%$ were undecided while none disagreed. Similarly, the open-ended question that sought to confirm the extent also corroborated this by affirming that frequent changes in government policies constitute one of the dynamism in the environment that influences the formation and implementation of HRM policies and practices that the organization adopts. Furthermore, 40\% strongly agreed that the type of ownership of their organisation influence adoption of HRM practices, 13.85 agreed, $29.75 \%$ were undecided while 15.38 disagreed. Likewise, the open-ended questionnaire also revealed that the nature and type of ownership, which is usually sole proprietorship and partnership and their corresponding features, influence the extent to which HRM practices are adopted. Conclusively, the table above revealed that most of the respondents with $83.08 \%$ agreed that the availability of funds to execute HRM policies influence its adoption; $10.26 \%$ were undecided while $6.66 \%$ disagreed. Similarly, the open-ended questionnaire also revealed that the extent to which financial resources influences adoption also affirmed that the availability and adequacy of financial resource is a sine qua non for effective adoption of HRM practices.

Table 3. Respondents Perception on the adoption of HRM practices and SMEs performance

\begin{tabular}{|l|l|c|c|c|c|c|}
\hline S/N & \multicolumn{1}{|c|}{ Items } & Strongly agree & Agree & Undecided & Disagree & $\begin{array}{l}\text { Strongly } \\
\text { Disagree }\end{array}$ \\
\hline 1 & $\begin{array}{l}\text { Work in this organisation is easier } \\
\text { because of laid down procedures and } \\
\text { adoption of HRM practices }\end{array}$ & $95(48.72)$ & $47(24.10)$ & $15(7.69)$ & $28(14.36)$ & $10(5.13)$ \\
\hline 2 & $\begin{array}{l}\text { The organisation achieves its stated goals } \\
\text { as a result of adoption of HRM practices }\end{array}$ & $93(47.69)$ & $99(50.77)$ & $3(1.54)$ & $0(0)$ & $0(0)$ \\
\hline 3 & $\begin{array}{l}\text { Customers/client expectations are met as } \\
\text { a result of adoption of HRM practices }\end{array}$ & $99(50.77)$ & $58(29.74)$ & $24(12.31)$ & $9(4.61)$ & $5(2.56)$ \\
\hline 4 & $\begin{array}{l}\text { Employees are motivated to stay with } \\
\text { this organisation as a result of the } \\
\text { adoption of HRM practices }\end{array}$ & $69(35.38)$ & $98(50.26)$ & $26(13.33)$ & $2(1.03)$ & $0(0)$ \\
\hline
\end{tabular}

Source: Researchers' Field Survey, 2019

Table 3 showed that $48.7 \%$ of the respondents strongly agree that the accomplishments of their work are easier because of laid down procedures that are established, $24.1 \%$ agreed, $7.69 \%$ were indifferent or undecided, $14.36 \%$ disagreed while $5.13 \%$ strongly disagreed. It shows that the establishment of procedures assists a great deal in the performance of tasks and the accomplishment of organizational goals. Also, the table showed that $47.69 \%$ per cent strongly agreed that the organization achieves its stated goals, $50.77 \%$ also agreed to the statement, $1.54 \%$ were indifferent. It means that most of the SMEs achieve the goals they set for themselves. Furthermore, the above revealed that $50.77 \%$ of the respondents strongly agreed that compensation packages encourage employees to achieve organizations objectives; $29.74 \%$ agreed, $12.31 \%$ were undecided while 7.16 disagreed. It implies that incentives in the form of compensation are given to committed and dedicated employees to encourage them to assist the organization to achieve the organizational goals. Finally, the table revealed that most of the respondents with $85.64 \%$ agreed that the organization has mechanisms that ensure that employees which constitute the most important asset are motivated to stay with the organization, $13.33 \%$ were undecided while 1.03 disagreed. It implies that the importance of human resource which constitutes the employees is recognized and that mechanisms in the form of motivational tools have been put in place to retain them.

\section{Test of Hypothesis}

Ho: Adoption of HRM practices by SMEs in Kwara State is not influenced by any factor(s).

Table 4. Multiple Regression Analysis showing the factors that influence the adoption of Human Resource Management Practices by SMEs

\begin{tabular}{|c|c|c|c|c|c|}
\hline Model & R-Squared & \multicolumn{2}{|c|}{ Adjusted R Squared } & \multicolumn{2}{|r|}{ Root MSE } \\
\hline 1 & 0.8128 & \multicolumn{2}{|c|}{0.7926} & \multicolumn{2}{|c|}{.37753} \\
\hline Source & Sum of Square & Df & Mean Square & $\mathbf{F}$ & Probability \\
\hline Model & 143.49759 & 4 & 10.8743999 & 74.29 & 0.0000 \\
\hline Residual & 10.689900 & 190 & 0.14253200 & & \\
\hline Total & 154.18749 & 194 & 11.016931 & & \\
\hline
\end{tabular}


Table 4 (cont.). Multiple Regression Analysis showing the factors that influence the adoption of Human Resource Management Practices by SMEs

\begin{tabular}{|l|l|l|lc|c|}
\hline Variable & Coef. & Std. Error & T & Sig & Beta \\
\hline Firm Size & 0.2961687 & 0.0635737 & 4.66 & 0.000 & 0.455103 \\
\hline Govt. Policy & 0.4276609 & 0.1623688 & 2.63 & 0.045 & 0.2189244 \\
\hline Ownership Type & 0.0799815 & 0.0475752 & 1.68 & 0.049 & 0.148262 \\
\hline $\begin{array}{l}\text { Financial } \\
\text { Availability }\end{array}$ & 0.7859462 & 0.911105 & 8.63 & 0.000 & 0.7616384 \\
\hline Cons & & & & & \\
\hline
\end{tabular}

Source: Researcher's Analysis, 2019 Using STATA 11.0 (Statistically significant at 5\%)

The regression analysis results obtained in the evaluation of factors that influenced the adoption of HRM practices show that the $\mathrm{R}^{2}$ Coefficient $(0.8128)$, which is the coefficient of determination, indicates that the explanatory variables account for $81.2 \%$ of the variation of factors that influence the adoption of HRM practices. Given the adjusted $\mathrm{R}^{2}$ of $80 \%$ with 0.0000 at a $5 \%$ level of significance. It is an indication that the independent variables in the model jointly and significantly explain the factors that influence the adoption of HRM practices. Furthermore, the coefficient of the constant as shown in Table 1 above indicates that there exists $164 \%$ increase in HRM practices irrespective of factors that influences its adoption. Also, the F-statistics (74.29) indicates that the variables (Firm size, Government policy, Ownership type and Financial Availability) jointly predict the factors that influence HRM practices in SMEs in Kwara State. Financial availability $(\beta=0.76 ; t=8.63 ; p<0.05)$ was significant. It implies that the availability of funds constitutes the most factor that influences the adoption of HRM practices by SMEs in Kwara State. Firm size was also significant with $(\beta=0.46 ; t=4.66 ; p<0.05)$. It implies that the adoption of HRM practices also depends on the size of SMEs. Although, ownership type $(\beta=0.15 ; \mathrm{t}=1.68 ; \mathrm{p}<0.05)$ and government policies $(\beta=0.21 ; \mathrm{t}=2.63 ; \mathrm{p}<0.05)$ were significant but very low.

The null hypothesis is rejected, and the alternative hypothesis is accepted, which states that there is a significant relationship between the adoption of HRM practices and the performance of SMEs in Kwara State. This result agrees with Sels, Delmotte, Maes, Faems and Forrier (2006), who asserted that the adoption of formal HRM practices may not always be possible because it is often too costly. The result is complementary to the previous findings by Mohammad (2012) who affirmed that firms of different sizes differ in the implementation of HRM practices. Tiwari and Saxena (2012) also opined that the adoption of human resource practices is influenced by some factors.

\section{Conclusion and Recommendations}

The study has offered a new dimension for a better understanding of how HRM practices can contribute to the success of SMEs, especially in Kwara State, Nigeria. The adoption of HRM practices, no doubt, is one of the fundamental factors that can influence the performance of SMEs in Kwara State, Nigeria. The organizations which implement HRM practices with dedication remain ahead of their competitors because such practices affect other variables, such as competitive advantage, job satisfaction, financial performance, service quality, employee commitment, in a positive manner, and leads to overall corporate performance. Thus, HRM practices are associated with higher work productivity, higher profits and an increase in the innovation capacity. Based on the findings of this study, factors such as financial availability and firm size will influence the extent of adopting HRM practices by SMEs. This study recommends that since the adequate financial capability is one of the factors that determine the adoption of HRM practices, funding facilities should be provided for SMEs to boost their ability to adopt HRM practices. In the same vein, the government should continue to come up with policies that will create an enabling environment that fosters encouragement of the adoption of HRM practices by SMEs. It is expected to facilitate their ability to grow and build up the required capacity for the promotion of sustainable development in the nation.

\section{References}

1. Abdulkadir, D.S. (2012). Strategic Human Resource Management and Organizational Performance in the Nigerian Insurance Industry: The Impact of Organizational Climate, Business Intelligence Journal 5(1), 8-20. Available at: https://pdfs.semanticscholar.orgg. 
2. Abdul Majeed, O. (2002). The Impact of SMEs on Nigerian Economic Development: A Case Study of Okin Biscuits Limited, Offa, Kwara State. An Undergraduate Research Project Submitted to the Economics, Usman Danfodio University, Sokoto, Nigeria. Available at: https://www.academia.edu/1651121.

3. Ajibade, A. P. (2013). Building Human Capital for Sustainable Development: Role of The University. A paper delivered on the occasion of the 2013 University of Ibadan Registry Discourse on Thursday, 26th September 2013. Available at: https://www.academia.edu/165112.

4. Audretsch, D., and Klepper S. (2000). Innovation, Evolution of Industry and Economic Growth. Elgar Reference Collection, International Library of Critical Writings in Economics, Cheltenham, U.K. and Northamptons. Available at: https://www.researchgate.net/publication/.

5. Ayanda, O. J., \& Danlami S., A. (2011). Strategic Human Resource Management and Organizational Performance in the Nigerian Manufacturing Sector: An Empirical Investigation. International Journal of Business and Management, 6(9), 46-57. Available at: https://www.academia.edu/115112.

6. Boxall, P., and Purcell, J. (2008). Strategy and Human Resource Management. Basingstoke, Palgrave Macmillan. Available at: https://www.koganpage.com.

7. Boxall, P. (1996). The Strategic HRM Debate and the Resource-Based View of the Firm, HRM Journal, 6(3), 59-75. Available at: https://www.academia.edu/011001.

8. Drucker, P. (1985). Innovation and Entrepreneurship. Oxford, Butterworth-Heinemann. Available at: https://www.koganpage.com.

9. Ibikunle, O.H. (2015). Performance Appraisal: Methods, Processes and Problems in Aremu, M.A and Isiaka, S.B (Ed), Contemporary Issues in Human Resources Management. 97-110, Ilorin: Doja Press. Available at: https://www.academia.edu/165112.

10. Lawal, A. A. (1998). Entrepreneurship Development in Small Scale Business (Lagos - Labson resource Nigeria Ltd. Available at: https://www.academia.edu/11982.

11. Madurapperuma, M. A. (2009). Informal HRM practices and level of performance in manufacturing SMEs in Sri Lanka, International Research Conference on Management and Finance organized by University of Colombo, Colombo, Sri Lanka. Available at: https://www.academia.edu/.

12. Mohammad, M.A. (2012). Factors Affecting Human Resource Practices in a Sample of Diversified Palestinian Organizations, Tourism and Management Studies International Conference, Algarve. Available at: https://EconPapers.repec.org/RePEc:eco:journ.

13. Mulhern, A. (1995). The SME sector in Europe: A broad perspective. Journal of Small Business Management, 33(3), 83-87. https://pdfs.semanticscholar.org.

14. Muogbo, U.S. (2013). The Impact of Strategic Management on Organisational Growth and Development (A Study of Selected Manufacturing Firms in Anambra State Journal of Business and Management (IOSR-JBM), 7(1), 24-32. Available at: www.iosr.org.

15. Ogunwoye, A.B. (2015). Impact of Human Resource Management Practices on Performance Small Scale Business in Osun State, Nigeria. Unpublished Mtech thesis in Ladoke Akintola University of Technology, Ogbomoso. Available at: https://www.researchgate.net/publication/310455811.

16. Ojokuku, R.M., Sajuyigbe, A.S. and Ogunwoye, A.B. (2014). Human Resource Management Practices and Small-Scale Business Performance: Evidence from Osun State, South Western Nigeria. Journal of Emerging Trends in Economics and Management Sciences (JETEMS), 5(7), 1-6. Available at: www.jetems.org.

17. Ojokuku, R.M. (2012). Human Resource Management Demands and Challenges in Small and Medium Scale Enterprises. International Journal of Economic Development Research and Investment, 3(3), 1-10. Available at: www.ijedr.org.

18. Okwuonu, E.W. (2009). Small Business Management, BHM 305 Course Material for Undergraduate Students of NOUN. Available at: https://pdfs.noun.edu.ng.

19. Okpara, J. O. (2011). Factors constraining the growth and survival of SMEs in Nigeria: Implications for poverty alleviation. Management Research Review, 34(2), 156-171. Available at: https://EconPapers.repec.org/RePEc:eco:journal.

20. Onugu, B. (2005). Small and Medium Enterprises in Nigeria (SMEs) Problem and Prospect. Being a dissertation submitted to St. Clement University in partial fulfilment of the Award of the degree of Doctor of Philosophy in Management. Available at: https://www.academia.edu/11982. 
21. Owualah, I. (1999). Developing SMES in Nigeria, Financial Standard, 21st May, 1999. Available at: http://financial standard newspaper articles/Developing SMEsinNigeria\&id=1927718.

22. Onwumere, I. (2000). Poverty Eradication and SMES. Being a paper delivered at a seminar on SMEs, Lagos.

23. Onwumere, J. (1992). The Nature and Relevance of SMEs in Economic Development. The Nigeria Banker October Edition. Available at: http://fNigeian banker review articles/Nature of SMEs in Economic develop Nigeria\&id=192963.

24. Osalor, P. (2010). Entrepreneurial Development in Nigeria. Retrieved on January 15, 2015. Available at: http://ezinearticles.com/?Entrepreneurial-Developmentin-Nigeria\&id=3562102.

25. Oshagbemi, J. (1983). An Evaluation of the Challenges and prospects of Micro and Small-Scale Enterprises in Nigeria. American International Journal of Contemporary Research, 2(4), 171-185. Available at: https://www.academia.edu/165112.

26. Oyeyinka, B.O. (2011). SMES: Issues, Challenges and Prospects. Being a paper delivered at FSS 2020 International Conference. Available at: https://www.academia.edu/681822.

27. Richard, A. (2009). Measuring Organisational Performance: Towards Methodological Best Practice. Journal of Management, 5(2), 29-42. Available at: https://pdfs.semanticscholar.org.

28.Robert, B. (1991). Economic Growth in a Cross Section of Countries. Quarterly Journal of Developmental Studies, Michigan, 8(2), 11-22. Available at: https://EconPapers.repec.org/RePEc:eco:journ3:2017-02-17.

29.Saka, R.O. (2009). Entrepreneurship Development, ENT 221 Course Materials for Undergraduate Students of NOUN. Available at: https://pdfs.noun.edu.ng.

30. Sangosanya, A. O. (2011). Firms Growth Dynamics in Nigeria's Manufacturing Industry: A Panel Analysis. Journal of Applied Econometric Review, 1(1), 24-27. Available at: https://www.researchgate.net/publication.

31.Schuler, R.S. (1992). Strategic Human Resource Management: Linking People with the needs of the Business. Organisational Dynamics Journal, 20(1), 19-32. https:/doi:10.11634/216796061318722.

32.Schuler, R.S. and Jackson, S.E. (1987). Linking competitive strategies with human resource management practices. Academy of Management Executive, 1(3), 207-19. Available at: https://www.scribd.com/document.

33.Schuler, R.S \& MacMillan I. C. (1984). Gaining Competitive Advantage through Human Resource Management Practices. Human Resource Management, Fall 1984, 23(3), 241-250. Available at: https://www.scribd.com/document.

34.Sels, L., Winnie, S.D., Delmotte, J., Maes, J., Faems, D., and Forrier, A. (2006). Linking HRM and Small Business Performance: An Examination of the Impact of HRM Intensity on the Productivity and Performance of Small Businesses. Small Business Economics, 26(1), 83-101. Available at: https://pdfs.semanticscholar.org.

35.Som, A. (2008). Innovative Human Resource Management and Corporate Performance in the Context of Economic Liberalization in India. The International Journal of Human Resource Management, 3(2), 1-17. https://doi.org/10.1348/014466600164426.

36.Subramanian, C., Ibrahim, H., Shamsudin, F. (2011). Linking Human Resource and Organizational Performance: Evidence from Small and Medium Organizations in Malaysia. Journal Pengurusan. 32(1), $27-37$. DOI: $10.11634 / 216796061302415$.

37. Tiwari, P. \& Saxena, K. (2012). Human Resource Management Practices: A Comprehensive Review. Pakistan Business Review, 1(2), 669-705. Available at: https://www.researchgate.net/publication/310455811. 